MEDIKA ALKHAIRAAT : JURNAL PENELITIAN KEDOKTERAN DAN KESEHATAN 1(3): 82-88

e-ISSN: 2656-7822, p-ISSN: 2657-179X

\title{
KORELASI ANTARA STATUS GIZI DAN KADAR HEMOGLOBIN PADA KEJADIAN ANEMIA IBU HAMIL TRIMESTER III
}

\author{
Mudyawati Kamaruddin ${ }^{1 *}$, Hasrawati ${ }^{2}$, Sitti Usmia $^{1}$, Jusni ${ }^{1}$, Misnawaty ${ }^{1}$, Ika Handayani ${ }^{1}$ \\ ${ }^{1}$ Midwifery Academy, Tahirah Al Baeti, Bulukumba, South Sulawesi, Indonesia \\ ${ }^{2}$ Public Health Center of Ponre, Gantarang Bantaeng Regency, South Sulawesi \\ *Corresponding author: Telp: +628111520603, email : mudya07@gmail.com
}

\begin{abstract}
ABSTRAK
Kejadian anemia sering dijumpai selama kehamilan dan menjadi penyebab utama peningkatan morbiditas dan mortalitas pada ibu hamil baik di Negara maju maupun Negara berkembang. Salah satu penyebab terjadinya anemia adalah defisiansi zat besi yang biasanya pada ibu hamil dihubungkan denganstatus gizi yang kurang memadai. Tujuan penelitian adalah untuk mengetahui korelasi antara status gizi dan kadar hemoglobin pada kejadian anemia ibu hamil trimester III. Metode penelitian dilakukan secara purposive sampling pada 30 sampel ibu hamil trimester III dengan kejadian anemia di wilayah kerja Puskesmas Ponre Kecamatan Gantarang Kabupaten Bulukumba. Faktor penentu status gizi yang diamati adalah Indeks Massa Tubuh (IMT) dan Lingkar Lengan Atas (LILA), yang dihubungkan dengan kadar Hemoglobin (Hb). Data dianalisis dengan uji Spearman's rho. Hasil analisis uji Spearman's rho menunjukkan ibu hamil trimester III yang berstatus gizi (IMT) kurang, mengalami anemia ringan sebesar 10,0\%, dan anemia sedang sebesar $3.3 \%$, walau masih ada responden dengan $\mathrm{Hb}$ normal (tidak anemia) yang mengalami IMT kurang (3.3\%). Sedangkan responden dengan IMT normal masih menunjukkan 3.3\% responden yang tidak mengalami anemia, sedangkan anemia ringan mengalami peningkatan menjadi $40.0 \%$, walau demikian tidak ditemukan anemia sedang. Penelitian ini menjadi menarik ketika nilai IMT responden yang beresiko obes juga mengalami anemia ringan sebesar 30\%. Pada hasil pengukuran LILA yang beresiko mengalami KEK, menunjukkan responden yang mengalami anemia ringan sebesar $43.3 \%$ dan anemia sedang 3.3\%, walau masih ada responden yang mempunyai Hb normal (tidak anemia) beresiko KEK. Adapun hasil pengukuran LILA yang tidak beresiko KEK, hanya terjadi pada responden yang mengalami anemia ringan (43,3\%). Walaupun demikian, karakteristik ibu hamil yang meliputi pendidikan, umur dan pengetahuan terhadap status gizi mempunyai andil yang cukup signifikan dalam mencegah terjadinya anemia. Hasil penelitian ini diharapkan dapat meningkatkan pemahaman masyarakat mengenai pentingya asupan makanan dan tablet Fe untuk perkembangan janin dan menjaga kesehatan ibu, utamanya berat badan yang meningkat sesuai usia kehamilan.
\end{abstract}

Kata kunci: Status gizi, kadar Hemoglobin, anemia, LILA, KEK

\section{ABSTRACT}

Anemia is often found during pregnancy and a major cause of increased morbidity and mortality in pregnant women in both developed and developing countries. One cause of anemia is iron deficiency, which is usually associated with inadequate nutritional status in pregnant women. This study was conducted to determine the correlation between nutritional status and hemoglobin levels in the incidence of anemia in third trimester pregnant women. This study was conducted by purposive sampling on 30 samples of third trimester pregnant women with anemia in Public Health Center of Ponre, Gantarang district, Bulukumba regency. The determinants of nutritional status observed were Body Mass Index (BMI) and Mid Upper Arm Circumference (MUAC), which were associated with hemoglobin (Hb) levels. Data was collected and analyzed by the Spearman's test. Based on the analysis of Spearman's test, the third trimester pregnant women with malnutrition 
MEDIKA ALKHAIRAAT : JURNAL PENELITIAN KEDOKTERAN DAN KESEHATAN 1(3): 82-88

e-ISSN: 2656-7822, p-ISSN: 2657-179X

status have mild anemia by 10.0\%, and moderate anemia by 3.3\%. Although remain respondents with normal hemoglobin (no anemia) who experience a lack of BMI (3.3\%). Whereas respondents with normal BMI showed 3.3\% of respondents who did not experience anemia, while mild anemia increased to be $40.0 \%$, although no moderate anemia was found. This study became interesting when the BMI value of respondents who were at risk of obesity also experienced to mild anemia by 30\%. In the measurement results of MUAC who are at risk of lack of chronic energy (LCE) showed respondents who experienced mild anemia by $43.3 \%$ and moderate anemia by $3.3 \%$, although there were still respondents who had normal $\mathrm{Hb}$ (not anemic) at risk of LCE. As for the results of MUAC measurements that are not at risk of LCE, it only occurs in respondents who have mild anemia (43.3\%). Nevertheless, the characteristics of pregnant women which include education, age and knowledge of nutritional status have a significant contribution in preventing anemia. The results of this study are expected to increase public understanding of the importance of food intake and Fe tablets for fetal development and maintaining maternal health, especially weight gain that increases with gestational age.

Keywords: Nutritional status, Hemoglobin levels, anemia, MUAC, LCE

\section{PENDAHULUAN}

Anemia masih merupakan masalah kesehatan di masyarakat Indonesia yang terkait dengan peningkatan risiko morbiditas dan mortalitas, terutama pada wanita hamil $^{1}$.Berdasarkan profil kesehatan Indonesia tahun 2010 bahwa prevalensi anemia pada ibu hamil sebesar 24,5\%. Sedangkan data Riskesdas (2013) menunjukkan prevalensi anemia ibu hamil di Indonesia sebesar 37,1\%. ${ }^{1}$ Angka kejadian anemia pada ibu hamil di kabupaten Bulukumba Kecamatan Gantarang, Sulawesi Selatan,terjadipeningkatan dari $20,06 \%$ pada bulan Januari-Desember 2015 menjadi 40\% pada bulan Januari-Maret 2016. ${ }^{2}$ Hal ini mengindikasikan bahwa anemia gizi besi masih menjadi masalah kesehatan masyarakat.Selain itu, kondisi lingkungan masyarakat di daerah Ponre tersebut masih jauh dari tingkat pemenuhan standar gizi nasional, yang kemungkinan dapat mempengaruhi terjadinya anemia di daerah tersebut secara signifikan.

Menurut Mangkuji B (2012), hubungan status gizi juga menjadi salah satu faktor penyebab anemia. ${ }^{3}$ Diketahui status gizi yang kurang dapat menyebabkan kadar darah merah dalam tubuh menurun sehingga dapat menyebabkan anemia pada ibu hamil. Wanita hamil dengan status gizi kurang memiliki kategori risiko tinggi keguguran, kematian bayi dalam kandungan, kematian bayi baru lahir, cacat dan berat lahir rendah. Selain itu umumnya pada ibu dengan status gizi kurang tersebut dapat terjadi 2 komplikasi yang cukup berat selama kehamilan yaitu anemia (kekurangan sel darah merah) dan pre eklampsia/eklampsia. ${ }^{4}$

Status Gizi pada ibu hamil dapat dilakukan dengan cara memeriksakan keadaan ibu hamildengan menimbang berat badan, Lingkar Lengan Atas (LILA), serta memeriksa kadar Hemoglobin $(\mathrm{Hb})$ ibu. Peningkatan berat badan yang adekuat akan memperkecil terjadinya resiko terjadinya persalinan Small Gestational Age (SGA) atau preterm. Faktor yang mempengaruhi besarnya kebutuhan berat badan ditentukan oleh tinggi badan dan berat badan. ${ }^{5}$ Adapun metode yang biasa digunakan dalam menentukan kondisi berat badan dan tinggi badan adalah Indeks Massa Tubuh (IMT) didefinisikan sebagai berat badan yang dibagi tinggi badan.

Adapun pengukuran LILA merupakan salah satu pilihan untuk penentuan status gizi ibu hamil, yaitu untuk mengetahui resiko kekurangan energi kronis (KEK) wanita usia subur (WUS). ${ }^{6}$ Sedangkan $\mathrm{Hb}$ adalah parameter yang digunakan untuk menetapkan prevalensi anemia. $\mathrm{Hb}$ merupakan senyawa pembawa oksigen pada sel darah merah. Penilaian status gizi dengan kadar $\mathrm{Hb}$ merupakan penilaian status gizi secara biokimia. ${ }^{7}$ Menurut Mitayani, 
MEDIKA ALKHAIRAAT : JURNAL PENELITIAN KEDOKTERAN DAN KESEHATAN 1(3): 82-88

e-ISSN: 2656-7822, p-ISSN: 2657-179X

dkk. (2013), LILA nilai normal adalah $23,5 \mathrm{~cm}$ dan kenaikan berat badan ibu selama masa kehamilan lebih kurang $10-12 \mathrm{~kg} .{ }^{5}$

Penelitian ini mencoba menghubungkan antara status gizi dan kadar hemoglobin pada kejadian anemia yang menjadi kasus sering terjadi pada ibu hamil trimester III di Puskesma Ponre, Bulukumba Sulawesi Selatan.

\section{METODOLOGI}

\section{Lokasi dan Jenis Penelitian}

Lokasi penelitian dilakukan di Puskesmas Ponre Kecamatan Gantarang Kabupaten Bulukumba selama 2 bulan yaitu bulan April sampai dengan Juni 2016. Desain penelitian yang digunakan pada penelitian ini adalah metode Purposive Sampling.

\section{Populasi dan Sampel}

Populasi penelitian adalah semua ibu hamil dengan kejadian anemia dan bermasalah pada status gizi di wilayah kerja Puskesmas Ponre Kecamatan Gantarang Kabupaten Bulukumba.Sedangkan sampel penelitian adalah populasi yang memenuhi kriteria inklusi dengan jumlah sampel 30 ibu hamil. Kriteria inklusi adalah ibu hamil trimester III dengan kejadian anemia yang bermasalah pada status gizi dan bersedia menjadi peserta dalam penelitian dengan menandatangani surat persetujuan atas dasar kesukarelaan (informed concent).

\section{Metode Pengumpulan Data}

Metode pengumpulan data dengan menggunakan data primer dimana peneliti melakukan penelitian langsung kepada subjek dengan mencatat tinggi badan dan berat badan untuk mengetahui nilai IMT, dan dilanjutkan dengan pengukuran LILA dan kadar Hb setiap subjek. Alat pengumpulan data yang digunakan adalah easy touch untuk mengukur kadar $\mathrm{Hb}$, pita LILA untuk mengukur lingkar lengan atas dan timbangan serta ukuran tinggi badan untuk pengukuran IMT. Wawancara, yaitu untuk memperoleh informasi tentang karakteristik dan keadaan umum subyek, misalnya umur, pekerjaan, pendidikan, dan seterusnya sesuai dengan pertanyaan berupa kuesioner yang telah disiapkan.

\section{Analisis Data}

Data akan dianalisis dengan uji analisis univariat dan bivariat. Batas kemaknaan menggunakan nilai $\mathrm{p}<0,05$. Hubungan antara dua variabel akan dianalisis dengan menggunakan rumus korelasi Pearson jika distribusinya normal dan Spearman jika distribusinya tidak normal. Besarnya risiko dinilai dengan uji Chi-Square $\left(X^{2}\right)$.

\section{HASIL DAN PEMBAHASAN}

\section{HASIL}

\section{Karakteristik sampel}

Variabel yang dinilai pada penelitian ini adalah umur, pekerjaan, pendidikan, IMT, Hemoglobin, dan LILA.

Table 1. Distribusi frekuensi berdasarkan umur responden di Puskesmas Ponre Kec. Gantarang Kab. Bulukumba

\begin{tabular}{lcc}
\hline $\begin{array}{l}\text { Kelompok } \\
\text { Umur }\end{array}$ & $\begin{array}{c}\text { Frekuensi } \\
(\mathrm{N})\end{array}$ & $\begin{array}{c}\text { Persen } \\
(\%)\end{array}$ \\
\hline 16-25 Tahun & 9 & 30,0 \\
26-35 Tahun & 17 & 56,7 \\
36-45 Tahun & 4 & 13,3 \\
\hline \multicolumn{1}{c}{ Total } & 30 & 100,0 \\
\hline
\end{tabular}

Secara deskripsi, sampel dengan jumlah 30 ibu hamil sebagai responden didominasi pada kelompok umur 26 - 35 tahun sebesar 56,7\%, sedangkan kelompok umur 16 - 25 tahun adalah $30,0 \%$ dan $13,3 \%$ untuk kelompok umur 36-45 tahun (Tabel 1).

Berdasarkan hasil distribusi frekuensi terhadap pekerjaan responden dengan menggunakan data primer yang diolah secara SPSS 16,0 dapat dilihat pada tabel 2, terlihat bahwa pekerjaan yang paling banyak adalah ibu rumah tangga (IRT) sebanyak 22 responden $(73.3 \%)$, diikuti oleh guru sebanyak 6 orang $(20,0 \%)$ dan wiraswasta serta mahasiswa masing-masing hanya 1 orang $(3,3 \%)$. 
MEDIKA ALKHAIRAAT : JURNAL PENELITIAN KEDOKTERAN DAN KESEHATAN 1(3): 82-88

e-ISSN: 2656-7822, p-ISSN: 2657-179X

Table 2. Distribusi frekuensi berdasarkan pekerjaan responden di Puskesmas Ponre Kec. Gantarang Kab. Bulukumba

\begin{tabular}{lcc}
\hline Pekerjaan & Frekuensi (N) & Persen $(\%)$ \\
\hline IRT & 22 & 73,3 \\
Mahasiswa & 1 & 3,3 \\
Wiraswasta & 1 & 3,3 \\
Guru & 6 & 20,0 \\
\hline Total & 30 & 100,0 \\
\hline
\end{tabular}

Table 3. Distribusi frekuensi berdasarkan pendidikan respondendi Puskesmas Ponre Kec. Gantarang Kab. Bulukumba

\begin{tabular}{ccc}
\hline Pendidikan & Frekuensi (N) & Persen (\%) \\
\hline SD & 5 & 16,7 \\
SMP & 4 & 13,3 \\
SMA & 12 & 40,0 \\
S1 & 9 & 30,0 \\
\hline Total & 30 & 100,0 \\
\hline
\end{tabular}

Sedangkan dari tabel 3 dapat diketahui dari 30 responden, tingkat pendidikan yang paling banyak adalah tingkat Sekolah Menengah Atas (SMA) yaitu 12 responden $(40,0 \%)$, diikuti oleh responden yang berpendidikan Strata-1 (S1) sebesar 30,0\%, Sekolah dasar (SD) $16,7 \%$ dan Sekolah Menengah Pertama (SMP) 13,3\%.

\section{Korelasi Indeks Massa Tubuh dan kadar} Hemoglobin
Perbedaan karakteristik responden berdasarkan kadar hemoglobin yang diklasifikasikan berdasarkan anemia menurut WHO (2000) sebagai berikut tidak anemia (normal) ditunjukkan dengan kadar $\mathrm{Hb}$ : 11-13 gr\%; anemia ringan $\mathrm{Hb}$ : 9-10 gr\%; anemia sedang Hb: 7-8 gr\% dan anemia: $\mathrm{Hb}<7$ gr\%.

Hasil uji perbandingan antara kelompok anemia di atas dengan variabel IMT pada tabel 4 menunjukkan bahwa IMT dengan kategori kurang, responden yang tidak mengalami anemia sebesar $3,3 \%$, dengan anemia ringan dan sedang masing-masing sebesar $10,0 \%$, dan $3.3 \%$. Adapun IMT dengan kategori Normal, responden yang tidak mengalami anemia sebesar 3,3\%, yang mengalami anemia ringan $40,0 \%$, dan tidak ada satupun responden yang mengalami anemia sedang. Sedangkan IMT dengan kategori beresiko menjadi obes, responden yang anemia ringan sebesar 30,0\%, dan tidak satupun responden yang mengalami anemia sedang begitupun pada kelompok tidak anemia. Berbeda dengan IMT dengan obes 1 terdapat responden yang tidak anemia sebesar $3,3 \%$, yang mengalami anemia ringan sebesar $6,7 \%$, walaupun tidak ditemukan responden yang mengalami anemia sedang. Korelasi antara IMT dan kadar hemoglobin diperoleh $p$ value 0,310 dimana $p$ value itu lebih besar dibanding a value $(0,310>0,05)$, hal ini berarti tidak ada hubungan yang nyata antara status IMT dan kejadian anemia yang beracuan pada pengukuran kadar hemoglobin.

Table 4. Hubungan antara IMT dengan kejadian anemia Responden di Puskesmas Ponre Kec. Gantarang Kab. Bulukumba

\begin{tabular}{|c|c|c|c|c|c|c|c|c|c|}
\hline \multirow{3}{*}{ Anemia $(\mathrm{Hb})$} & \multicolumn{8}{|c|}{ Status Gizi (IMT) } & \multirow{3}{*}{$\begin{array}{c}\text { P. } \\
\text { Value }\end{array}$} \\
\hline & \multicolumn{2}{|c|}{ Kurang } & \multicolumn{2}{|c|}{ Normal } & \multicolumn{2}{|c|}{$\begin{array}{c}\text { Beresiko } \\
\text { Menjadi Obes }\end{array}$} & \multicolumn{2}{|c|}{ Obes 1} & \\
\hline & $\mathrm{N}$ & $\%$ & $\mathrm{~N}$ & $\%$ & $\mathrm{~N}$ & $\%$ & $\mathrm{~N}$ & $\%$ & \\
\hline Tidak Anemia & 1 & 3.3 & 1 & 3.3 & 0 & 0. & 1 & 3.3 & \\
\hline $\begin{array}{l}\text { Anemia ringan } \\
\text { Anemia }\end{array}$ & 3 & 10.0 & 12 & 40.0 & 9 & 30.0 & 2 & 6.7 & .310 \\
\hline Sedang & 1 & 3.3 & 0 & 0. & 0 . & 0. & 0 . & 0. & \\
\hline Total & 5 & 16.7 & 13 & 43.3 & 9 & 30.0 & 3 & 10.0 & \\
\hline
\end{tabular}


MEDIKA ALKHAIRAAT : JURNAL PENELITIAN KEDOKTERAN DAN KESEHATAN 1(3): 82-88

e-ISSN: 2656-7822, p-ISSN: 2657-179X

Korelasi Lingkar Lengan Atas dan kadar Hemoglobin

Pada tabel 5 menjelaskan bahwa pengukuran LILA yang beresiko mengalami KEK tersebar pada semua kelompok responden baik tingkat $\mathrm{Hb}$ normal, anemia ringan maupun sedang (masing-masing 10\%, 43,3\% dan 3,3\%). Sedangkan yang tidak beresiko hanya terdapat pada kelompok responden yang mengalami anemia ringan yaitu sebesar $43,3 \%$.

Table 5. Hubungan antara LILA dengan kejadian anemia responden di Puskesmas Ponre Kec. Gantarang Kab. Bulukumba

\begin{tabular}{|c|c|c|c|c|c|}
\hline \multirow{3}{*}{ Anemia $(\mathrm{Hb})$} & \multicolumn{4}{|c|}{$\begin{array}{l}\text { Status Gizi (Lila) } \\
\end{array}$} & \multirow{3}{*}{ P. Value } \\
\hline & \multicolumn{2}{|c|}{ Beresiko KEK } & \multicolumn{2}{|c|}{ Tidak Beresiko KEK } & \\
\hline & $\mathrm{N}$ & $\%$ & $\mathrm{~N}$ & $\%$ & \\
\hline Tidak Anemia & 3 & 10.0 & 0 & .0 & \\
\hline Anemia ringan & 13 & 43.3 & 13 & 43.3 & \\
\hline $\begin{array}{l}\text { Anemia } \\
\text { Sedang }\end{array}$ & 1 & 3.3 & 0 & 0 . & .096 \\
\hline Total & 17 & 56.7 & 13 & 43.3 & \\
\hline
\end{tabular}

Akan tetapi, dari nilai p-value yang diperoleh menunjukkan bahwa antara status gizi dengan pengukuran LILA dan kejadian anemia tidak terjadi hubungan yang nyata.

\section{PEMBAHASAN}

Status Gizi adalah ekspresi dari keadaan keseimbangan dalam bentuk variabel tertentu atau perwujudan dari nutrisi dalam bentuk variabel tertentu. ${ }^{8}$ Penelitian ini dilakukan untuk mengetahui hubungan status gizi ibu hamil didasarkan pada indeks massa tubuh, pengukuran lingkar lengan atas terhadap kadar hemoglobin yang terkandung pada sel darah merah setiap ibu hamil yang dijadikan sebagai responden penelitian ini. Pada penelitian ini, pemantauan status gizi ibu hamil yang dihubungkan dengan kejadian anemia pada saat kehamilan trimester III menunjukkan bahwa tidak ada hubungan yang signifikan.Hal yang dapat menyebabkan tidak adanya hubungan antara status gizi dengan kejadian anemia yaitu dapat dipengaruhi oleh beberapa faktor, antara lain usia responden, pendidikan, paritas dan usia kehamilan.

Pada penelitian ini menunjukkan sebagian besar ibu hamil terdistribusi pada kelompok umur 16 - 25 tahun, 26 - 35 tahun, dan $36-45$ tahun dengan masing-masing sebesar $30,0 \%$.
Diketahui kelompok umur antara 16 sampai 31 tahun termasuk dalam rentang usia subur bagi wanita. Hal ini sesuai dengan Depkes (2009), wanita subur adalah wanita usia 15-49 tahun dengan keadaan organ reproduksi berfungsi dengan baik, baik dengan status belum kawin, kawin maupun janda yang kemudian diperbaharui oleh BKKBN (2011) bahwa wanita usia subur adalah wanita usia antara 18 sampai 49 tahun dengan keadaan organ reproduksi berfungsi dengan baik, baik dengan status belum kawin, kawin maupun janda. ${ }^{9}$

Selain itu, karakteristik ibu hamil juga dilihat dari tingkat pekerjaan dan pendidikan.Pada penelitian ini, pekerjaan ibu hamil yang mayoritas adalah sebagai ibu rumah tangga $(73,3 \%)$ dengan tingkat pendidikan yang terbanyak adalah sekolah menengah atas $(40,0 \%)$. Hal ini tidak mengherankan karena daerah peneltian ini di Kecamatan Gantarang, dimana lokasi daerah ini cukup jauh dari pusat kota dan biasanya sebagian masyarakat desa hanya dapat mengecap pendidikan tertinggi sampai tingkat sekolah menengah dengan alasan klise bahwa ibu rumah tangga adalah ratu dalam rumahnya, dimana segala urusan kepala keluarga akan dilimpahkan kepada mereka apabila suami bekerja di luar daerah. Kebenaran hampir semua kaum lelaki di daerah 
Gantarang ini bekerja sebagai tenaga kerja Indonesia (TKI) di Malaysia (Sumber: setiap responden, 2016).

Pada penelitian ini, pendidikan tingkat SMA lebih mendominasi dibanding pendidikan yang lain, hal inilah yang mendukung pengetahuan ibu terhadap gizi saat hamil lebih adequat dibanding hanya berpendidikan SD atau SMP. Menurut Nurlaela, A. (2013) bahwa Pendidikan merupakan keadaan yang sangat penting untuk terbentuknya tindakan seseorang. ${ }^{10}$ Selain itu pula, dengan tingkat pendidikan yang lebih baik akan membantu mengabsorbsi keterangan atau informasi yang diberikan oleh pihak kesehatan pada saat konseling berlangsung. Dari hasil penelitian terbukti bahwa perilaku yang didasari pengetahuan akan lebih mengerti dengan pola hidup yang sehat, oleh sebab itulah tidak ditemukan kasus anemia yang berarti di Puskesmas Ponre Kec. Gantarang Kab. Bulukumba. ${ }^{11}$

Status gizi ibu hamil dengan kejadian anemia pada masa-masa kehamilan, dapat dipantau dengan nilai IMT dan pengukuran LILA ibu hamil.Pada penelitian ini, dengan nilai IMT yang kurang dapat mempengaruhi status $\mathrm{Hb}$ ibu hamil sehingga tidak mengherankan kejadian anemia ringan maupun sedang dialami oleh ibu hamil di puskesmas Ponre cukup besar (Tabel 5). Hal ini diketahui dengan nilai IMT yang kurang berarti status gizi ibu hamil pun mengalami penurunan, berdasarkan teori yang ada bahwa status gizi yang kurang dapat menyebabkan kadar darah merah dalam tubuh menurun sehingga dapat menyebabkan anemia pada ibu hamil. Namun, dapat memperoleh suplemen zat besi dari makanan yang alami dari tumbuhan. ${ }^{4}$ Selain mengkonsumsi suplemen zat besi dari tablet besi (tablet Fe). Sebaliknya dengan nilai IMT yang melebihi batas normal akan cenderung beresiko obesitas dengan berbagai tingkatan. Hal ini pula ditunjukkan pada penelitian ini, bahwa dengan IMT kategori beresiko menjadi obesitas maupun obesitas tingkat 1 , rata-rata responden mengalami anemia ringan walaupun tidak sampai pada tingkat anemia sedang atau berat. Kemungkinan hal ini disebabkan oleh pola asupan makanan sehingga dapat mempengaruhi berat badan.Diketahui berat badan adalah salah satu faktor penentu nilai IMT.

Sebagaimana telah dijelaskan sebelumnya, pengukuran LILA merupakan salah satu alat pemantau status gizi ibu hamil, dengan mengetahui nilai LILA maka akan mudah mendeteksi seorang ibu hamil dalam kategori resiko atau tidak resiko kekurangan energi protein. Pada penelitian yang telah dilakukan berdasarkan data sekunder di Puskesmas Ponre Kec. Gantarang terhadap ibu hamil yang mengalami KEK diperolehpengukuran LILA yang beresiko mengalami KEK tersebar pada semua kelompok responden baik tingkat $\mathrm{Hb}$ normal, anemia ringan maupun sedang (Tabel 6). ${ }^{11,12} \mathrm{Hal}$ ini didukung dengan nilai batas antara yang beresiko mengalami KEK maupun yang tidak beresiko sangat tipis, diketahui untuk ibu hamil yang beresiko mengalami KEK berada pada LILA yang kurang dari $23,5 \mathrm{~cm}$ sedangkan yang tidak beresiko berada pada LILA yang lebih besar dan sama dengan $23,5 \mathrm{~cm}$. Selisih antara nilai batasan sangatlah tipis.Adapun ibu hamil yang tidak beresiko mengalami KEK, didapatkan hanya pada kelompok ibu hamil yang mengalami anemia ringan.Selain karena selisih yang sangat tipis antara yang beresiko dan tidak beresiko terjadi KEK juga mungkin disebabkan oleh faktor pendataan saat pengisian kuesioner responden.

Walaupun hasil penelitian ini tidak sejalan dengan hasil penelitian yang dilakukan oleh Etik W., (2015) tentang hubungan status gizi dengan kejadian anemia pada ibu hamil trimester III di Puskesmas Pleret Bantul dan penelitian oleh Triwidiyantari D., (2011) tentang hubungan status gizi dengan anemia pada ibu hamil trimester III di Puskesmas Garuda Kota Bandung, dimana dari kedua hasil peneliti tersebut terdapat hubungan yang nyata antara status gizi dengan kejadian ibu hamil trimester III. ${ }^{13,14}$ Akan tetapi, perlu diketahui bahwa kadar Hemoglobin atau 
MEDIKA ALKHAIRAAT : JURNAL PENELITIAN KEDOKTERAN DAN KESEHATAN 1(3): 82-88

e-ISSN: 2656-7822, p-ISSN: 2657-179X

kejadian anemia terjadi bukan hanya dipengaruhi oleh status gizi yang dilihat dari hasil IMT, dan ukuran LILA. Namun, jarak kehamilan sangat mempegaruhi terjadinya anemia saat kehamilan.Kehamilan yang berulang dalam waktu singkat akan menguras cadangan zat besi ibu. Pengaturan jarak kehamilan yang baik minimal dua tahun menjadi penting untuk diperhatikan sehingga badan ibu siap untuk menerima janin kembali tanpa harus menghabiskan cadangan zat besinya saat kehamilan berlangsung. ${ }^{15}$

Disimpulkan bahwa Beberapa faktor yang ikut menentukan status gizi ibu hamil seperti nilai Indeks Massa Tubuh, pengukuran Lingkar Lengan Atas dan kadarHemoglobin pada sel darah merah pada 30 responden ibu hamil tidak ada satupun yang mempunyai hubungan yang signifikan dengan terjadinya anemia. Walaupun demikian, karakteristik ibu hamil yang meliputi pendidikan, umur dan pengetahuan terhadap status gizi mempunyai andil yang cukup signifikan dalam mencegah terjadinya anemia. Hasil penelitian ini diharapkan dapat meningkatkan pemahaman masyarakat mengenai pentingya asupan makanan dan tablet $\mathrm{Fe}$ untuk perkembangan janin dan menjaga kesehatan ibu, utamanya berat badan yang meningkat sesuai usia kehamilan.

\section{DAFTAR PUSTAKA}

1. Departmen Kesehatan Republik Indonesia. Laporan Hasil Riset Kesehatan Dasar Indonesia (Riskesdas). 2013

2. Pusat Kesehatam Masyarakat Ponre. Profil Kesehatan kabupaten Bulukumba. 2016.

3. Mangkuji B. Asuhan kebidanan 7 langkah SOAP. Jakarta, Buku kedokteran EGC. 2012.

4. Rukiah Y, dkk. Asuhan Kebidanan. Jakarta, Trans Info Media. 2011.

5. Mitayani dkk. Buku Saku Ilmu Gizi. Jakarta, Trans Info Media. 2013.

8. Sibagariang EE. Gizi Dalam Kesehatan Reproduksi. Jakarta. Trans Info Media. 2011.

10. Nurlaela, A. 2013.(http://adamnurlaela.blogspot.co.id/20 13/07/hubungan-tingkat-pendidikandan.html)

12. Hidayat, A.A. 2014. Metode penelitian kebidanan dan Teknik Analisis Data Contoh Aplikasi Studi Kasus. Jakarta: Salemba medika.

13. Susanto, S. 2007. (http://digilib.unila.ac.id/2382/11/BAB\%20 II.pdf ).

14. Tesis, U. 2011. (http://hadiriyadi.blogspot.co.id/2013/01/m engukur-status-gizi-dengan-indeks.html)

15. Uswatun, T. 2013. (http://digilib.unimus.ac.id/download.php?i $\mathrm{d}=6888$ ) 